University of Montana

ScholarWorks at University of Montana

\title{
Biogeochemical Consequences of Rapid Microbial Turnover and Seasonal Succession in Soil
}

\author{
S. K. Schmidt \\ E. K. Costello \\ D. R. Nemergut
}

Cory C. Cleveland

The University of Montana, cory.cleveland@umontana.edu

S. C. Reed

See next page for additional authors

Follow this and additional works at: https://scholarworks.umt.edu/decs_pubs

Part of the Ecology and Evolutionary Biology Commons Let us know how access to this document benefits you.

\section{Recommended Citation}

Schmidt, S. K.; Costello, E. K.; Nemergut, D. R.; Cleveland, Cory C.; Reed, S. C.; Weintraub, M. N.; Meyer, A. F.; and Martin, A. M., "Biogeochemical Consequences of Rapid Microbial Turnover and Seasonal Succession in Soil" (2007). Ecosystem and Conservation Sciences Faculty Publications. 12. https://scholarworks.umt.edu/decs_pubs/12

This Article is brought to you for free and open access by the Ecosystem and Conservation Sciences at ScholarWorks at University of Montana. It has been accepted for inclusion in Ecosystem and Conservation Sciences Faculty Publications by an authorized administrator of ScholarWorks at University of Montana. For more information, please contact scholarworks@mso.umt.edu. 


\section{Authors}

S. K. Schmidt, E. K. Costello, D. R. Nemergut, Cory C. Cleveland, S. C. Reed, M. N. Weintraub, A. F. Meyer, and A. M. Martin

This article is available at ScholarWorks at University of Montana: https://scholarworks.umt.edu/decs_pubs/12 


\title{
BIOGEOCHEMICAL CONSEQUENCES OF RAPID MICROBIAL TURNOVER AND SEASONAL SUCCESSION IN SOIL
}

\author{
S. K. Schmidt, ${ }^{1,4}$ E. K. Costello, ${ }^{1}$ D. R. Nemergut,${ }^{2,3}$ C. C. Cleveland, ${ }^{3}$ S. C. Reed, ${ }^{1,3}$ M. N. Weintraub, ${ }^{1}$ \\ A. F. Meyer, ${ }^{1}$ And A. M. Martin ${ }^{1}$ \\ ${ }^{1}$ Department of Ecology and Evolutionary Biology, University of Colorado, Boulder, Colorado 80309 USA \\ ${ }^{2}$ Environmental Studies Program, University of Colorado, Boulder, Colorado 80309 USA \\ ${ }^{3}$ Institute of Arctic and Alpine Research, University of Colorado, Boulder, Colorado 80309 USA
}

Abstract. Soil microbial communities have the metabolic and genetic capability to adapt to changing environmental conditions on very short time scales. In this paper we combine biogeochemical and molecular approaches to reveal this potential, showing that microbial biomass can turn over on time scales of days to months in soil, resulting in a succession of microbial communities over the course of a year. This new understanding of the year-round turnover and succession of microbial communities allows us for the first time to propose a temporally explicit $\mathrm{N}$ cycle that provides mechanistic hypotheses to explain both the loss and retention of dissolved organic $\mathrm{N}$ (DON) and inorganic $\mathrm{N}$ (DIN) throughout the year in terrestrial ecosystems. In addition, our results strongly support the hypothesis that turnover of the microbial community is the largest source of DON and DIN for plant uptake during the plant growing season. While this model of microbial biogeochemistry is derived from observed dynamics in the alpine, we present several examples from other ecosystems to indicate that the general ideas of biogeochemical fluxes being linked to turnover and succession of microbial communities are applicable to a wide range of terrestrial ecosystems.

Key words: microbial community composition; nitrogen cycle; seasonal dynamics; succession; undersnow growth.

\section{INTRODUCTION}

Microorganisms experience time and space on scales that are currently under-appreciated in the fields of ecology and evolutionary biology. A typical bacterium is almost $1 \times 10^{7}$ times smaller and can have a generation time $1 \times 10^{7}$ times shorter than an animal such as an elephant. To put this in perspective, an elephant is about $1 \times 10^{7}$ times smaller than the planet Earth (Koch 1976). Therefore, in many respects bacteria (as well as archaea and the slightly larger microbial eukaryotes), live on a scale that is closer to the molecular world than it is to the world of macroorganisms like elephants and plants (Purcell 1977). In the microbial world, time is speeded up relative to our experience. A combination of short generation times, rapid evolutionary potential, and large surface-to-volume ratios give soil microbes distinct advantages over plants and animals in terms of how quickly they can process resources and adapt to change in natural environments. Therefore, microorganisms have the ability to perceive and respond to environmental changes on a much faster time scale than plants and animals. For example, microbes can sense changing gradients of limiting resources in seconds to minutes, allowing them to come out of dormancy and even move

Manuscript received 1 February 2006; revised 28 June 2006; accepted 17 July 2006. Corresponding Editor: R. B. Jackson. For reprints of this Special Feature, see footnote 1, p. 1343.

${ }^{4}$ E-mail: steve.schmidt@colorado.edu along environmental gradients within minutes in response to pulses of limiting resources (e.g., GarciaPichel and Pringault 2001, Fenchel 2002).

The profound implications of scale are especially important in the soil microenvironment. Arguably, soil comprises the most spatially and temporally heterogeneous environment on Earth; a combination of complex physical structure, geochemistry, and dramatic seasonal fluctuations in temperature, moisture and nutrient availability are all experienced by soil microbes at micro-scales. It is therefore no surprise that soils have been shown to have higher diversity and biomass of microbes compared with other environments (Torsvik et al. 2002). Indeed, the total number of microbial species in soil remains unknown (Schloss and Handelsman 2004). Yet, the nature of soil itself has restricted our view of microbial ecology in terrestrial environments. The small spatial scale of soil microbial community dynamics, soil's complex matrix of minerals and organic matter have made it difficult to extract microbes or their cellular constituents from soil or to use cell sorting and DNA probing techniques that have led to major recent advances in marine microbial ecology (e.g., Boetius et al. 2000, Könneke et al. 2005). In addition, and perhaps most importantly, most soil microbes have yet to be cultured outside of the soil environment (Rappé and Giovannoni 2003, Janssen 2006). However, with the advent of cultivation-independent assessments of microbial diversity, high-throughput DNA sequencing tech- 
nologies and advances in isotopic approaches, we are beginning to glimpse the vast diversity and adaptability of microbes in soil, both from spatial and temporal perspectives.

Here, we explore how recent advances in molecular and isotope techniques are allowing us to begin to understand the dynamics of microbial communities and how those dynamics link to major biogeochemical processes in soil. In particular we focus on recent work in the tundra and forests of Colorado that links turnover and seasonal succession of microbial communities with the timing and magnitude of nitrogen $(\mathrm{N})$ and carbon (C) flow through those systems.

\section{Microbial Turnover and Succession in SoIl}

\section{High rates of microbial turnover in soil}

Initial evidence of high rates of microbial turnover in alpine soils came from ${ }^{15} \mathrm{~N}$-dilution approaches previously used to demonstrate high rates of microbial biomass $\mathrm{N}(\mathrm{MBN})$ turnover in a diversity of forest soils (e.g., Stark and Hart 1997). In soils of three widespread alpine plant communities of the Rocky Mountains, Fisk et al. (1998) found that microbial immobilization of $\mathrm{N}$ exceeded gross rates of $\mathrm{N}$ mineralization. The underlying reason for the rapid immobilization of mineralized $\mathrm{N}$ was that the microbial pool was turning over much faster than was previously thought creating a sustained $\mathrm{N}$ sink. Fisk et al. (1998) estimated a mean residence time of 0.05 years for $\mathrm{N}$ in the microbial biomass, which translates to a turnover time of 18 days. This estimate agreed with the work of Lipson et al. (2001) who used different methods, data sets, and field sites than Fisk et al. (1998) and found that amino acid $\mathrm{N}$ turns over every 13 days through the microbial biomass. While the estimates of Fisk et al. (1998) and Lipson et al. (2001) are towards the low end of the range of microbial $\mathrm{N}$ turnover times in soils (e.g., compare Holmes and Zak 1999), faster turnover times have been reported for more productive systems; for example, Perakis and Hedin (2001) estimated a microbial $\mathrm{N}$ turnover time of 9 days in an unpolluted forested ecosystem in Chile. Other studies (e.g., Davidson et al. 1992, Stottlemeyer and Toczydlowski 1999, Grenon et al. 2005) also indicate that high rates of gross $\mathrm{N}$ mineralization and immobilization are common in diverse ecosystems, suggesting that the turnover of microbial $\mathrm{N}$ is also rapid.

Recent studies point to the rhizosphere as the site of the most rapid $\mathrm{N}$ mineralization and microbial turnover in soil (Hamilton and Frank 2001, Ostle et al. 2003, Staddon et al. 2003, Butler et al. 2004, Rangle-Castro et al. 2005). The rhizosphere is an environment where root exudates stimulate microbes that have the potential to rapidly initiate growth following a DOM pulse. These growth spurts lead to increased predation by protists and larger soil eukaryotes (reviewed by Clarholm 1985, Moore et al. 2003) resulting in increased microbial turnover and leakage of DON and DIN back into the rhizosphere environment. Even if plants only take up a small fraction of the microbial $\mathrm{N}$ released in the rhizosphere this is an important source of $\mathrm{N}$ for plants in natural ecosystems. In alpine soils, plants only have to capture about $5 \%$ of the $\mathrm{N}$ released by turnover of microbial $\mathrm{N}$ to meet their $\mathrm{N}$ demands for growth (Fisk et al. 1998). The ecosystem-level consequences of the intermeshing of rapid microbial $\mathrm{N}$ turnover and the slower cycling of plant $\mathrm{N}$ are discussed in more detail below (See A Temporally Explicit $N$ Cycle).

\section{Seasonal succession in microbial communities}

That some microbial communities can undergo successional changes on time scales of less than one year has been hypothesized since the 1950s (see references in Thormann et al. 2003). Most data supporting this idea have come from studies of enzyme activity (reviewed by Sinsabaugh et al. 2002, Sinsabaugh 2005) and fungal community structure (reviewed by Thormann et al. 2003) during the decomposition of organic matter in soil. In addition, work examining microbial succession in recently deglaciated soils supports the idea that microbial communities can show successional changes on much shorter time scales than succession of plant communities (see Nemergut et al., in press, and references therein).

Our initial studies of seasonal succession in alpine soils grew out of the turnover studies discussed above and indicated that many microbial functional groups show dramatic seasonal changes (Lipson et al. 2002). As an example, Fig. 1 shows the seasonal variation of salicylate-mineralizing microbes in alpine meadow soils. In agreement with other independent measures of biomass and enzymatic activity (Lipson et al. 1999), microbial biomass in this system peaked under latewinter snow packs. In addition, soil cellulase activity peaks in late winter (Lipson et al. 2002), explaining why a high percentage of plant litter decomposition takes place in the winter in many seasonally snow-covered ecosystems (Taylor and Jones 1990, Hobbie and Chapin, 1996, Schmidt and Lipson 2004). The under-snow peak in microbial biomass and cellulase activity was followed by a precipitous biomass decline during snowmelt that resulted in a large release of available DON and DIN. This $\mathrm{N}$ is then taken up by plants and later successional microbes (Mullen et al. 1998, Jaeger et al. 1999) or is lost to the system via leaching (Brooks et al. 1998). The release of available $\mathrm{N}$ during snowmelt coincides with the highest year-round levels of protease activity (Lipson et al. 1999) indicating that the snow-melt microbial community is largely fueled by protein released from the crash of the winter microbial community. Microbial biomass has a much higher protein concentration than plant litter, for example bacteria are over $50 \%$ protein by weight (Neidhardt et al. 1990). Finally, the microbial community that develops in the summer is fueled mostly by rhizodeposition (Lipson et al. 2002). In summary, substrate availability and enzyme activity data indicate that there is a yearly succession of dominant substrates 

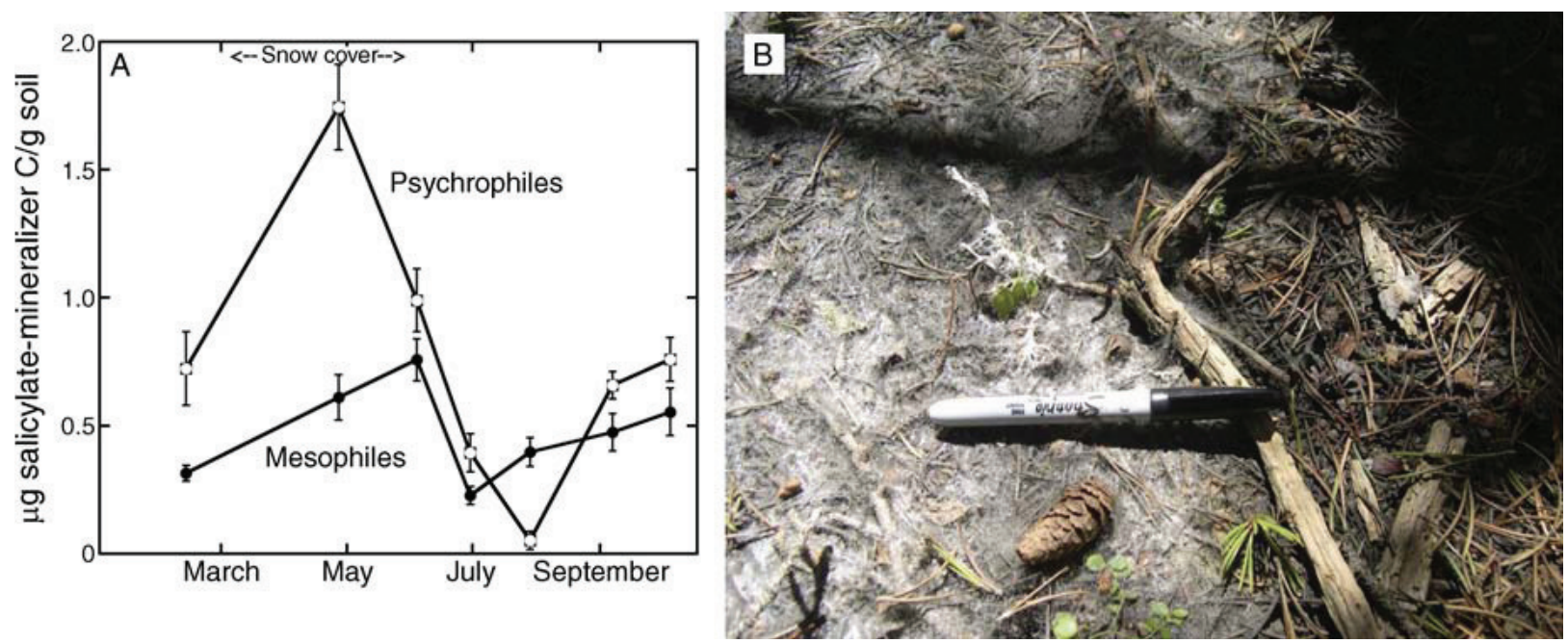

FIG. 1. Two demonstrations of the extreme seasonality of microbial communities in soil. (A) Seasonal changes (mean \pm SE) in soil microbes that mineralize salicylic acid to $\mathrm{CO}_{2}$ at $3^{\circ} \mathrm{C}$ (psychrophiles) and $22^{\circ} \mathrm{C}$ (mesophiles). Soil temperatures $(5 \mathrm{~cm}$ depth) ranged from $-0.5^{\circ} \mathrm{C}$ (27 April) to a summer average of $11^{\circ} \mathrm{C}\left(30 \mathrm{June}, 29 \mathrm{July}\right.$, and 7 September) and $6^{\circ} \mathrm{C}$ in the fall $(5 \mathrm{October})$. Soils were frozen too solid (less than $-5^{\circ} \mathrm{C}$ ) to measure soil temperature on the first sampling date (11 February). The arrows on either side of "snow cover" indicate the temporal extent of snow cover during the study. Data for mesophilic microbial biomass for June, July, and August were previously published (Schmidt et al. 2000). (B) Saprotrophic "snow mold" forming a dense hyphal mat on litter of a spruce-pine forest that shows high levels of under-snow $\mathrm{CO}_{2}$ flux (Monson et al. 2006). This snow mold disappears within days of the soils becoming snow-free.

for microbial growth progressing from carbon polymers/ phenolics (winter) to proteins (snowmelt) to rhizodeposition (summer).

Observation of the seasonal succession of functional groups prompted phylogenetic studies of seasonal fluctuations of the microbial community in tundra soils. From a broad phylogenetic perspective, fungi dominate the under-snow biomass and bacteria are more active in the summer (Lipson et al. 2002, Schadt et al. 2003). These observations are in agreement with studies from other systems that also show that fungi dominate microbial biomass in the winter (Myers et al. 2001, Bardgett et al. 2005). At a finer taxonomic scale, the phylogenetic makeup of both the bacterial and fungal communities change dramatically from season to season (Schadt et al. 2003, Lipson and Schmidt 2004). In fact, the soil bacterial community shows more seasonal than spatial variation in alpine tundra soils (Lipson and Schmidt 2004). This seasonal succession of bacteria (Fig. 2B) also provides mechanistic insights into the seasonality of biogeochemical fluxes from these soils. For example, the winter-dominant $\mathrm{CFB}$ group contains many known degraders of cellulose and lignin and their presence under the snow agrees with independent observations of high de-polymerase activity and litter decomposition under the snow. Furthermore, although much less is known about the Acidobacteria and Verrucomicrobia, the successional progression of substrates discussed above indicates that some of these organisms may be associated with snowmelt proteolysis (Acidobacteria) and rhizosphere dynamics (Verrucumicrobia). In addition, the Acidobacteria showed the least seasonal variation among the major bacterial divisions in our study (Fig. 2B; Lipson and Schmidt 2004), indicating that sub-groups of the Acidobacteria may be involved in many other soil processes besides protein degradation. Moreover, their sustained presence in the soil may indicate that, in general, they are more $K$ selected than some other groups of bacteria (see Fierer et al. 2007). It should be noted, however, that much more detailed molecular work is needed to definitively link phylogeny and function in soil ecosystems, especially for largely uncultured groups such as the Acidobacteria and Verrucomicrobia.

Microbial eukaryotes also show significant seasonal succession, but in all seasons fungi dominate alpine soils (Schadt et al. 2003). Within the fungi there are also large seasonal changes in the major groups of the fungi (Ascomycetes, Basidiomycetes, and Zygomycetes), but the most dramatic changes occur within previously unknown subphylum level clades of Ascomycetes (Fig. 2A). The functional roles of these new groups of fungi remain to be uncovered but it is apparent in Fig. 2A that Group II shows less seasonal fluctuation than Group I and therefore may be more $K$-selected than Group I. Conversely Group I is probably more $r$-selected and its rapid rise during the growing season may indicate that it is a rhizosphere inhabitant. Indeed, recent soil metagenomic studies have uncovered Group I during the growing season in forest soils from Canada to Costa Rica and have confirmed that the closest known relatives to this group are relatively fast growing ascomycetous yeasts (T. M. McLenon, personal communication).

Evidence of seasonal succession of microbial communities in soils is also accumulating from ecosystems other 


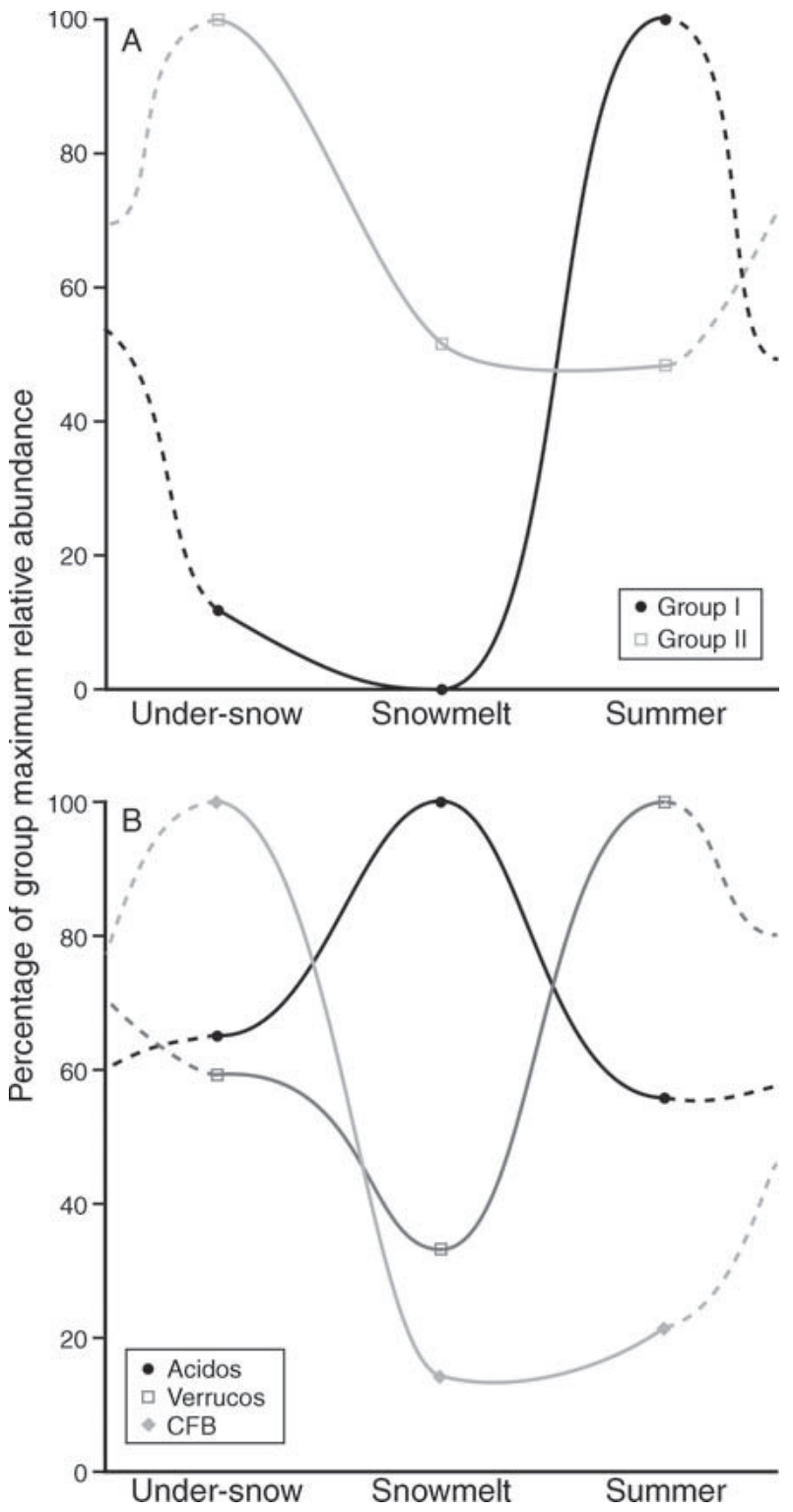

FIG. 2. Seasonal succession of some major microbial groups in alpine dry meadows. (A) Novel ascomycete fungal groups and (B) the dominant bacterial divisions in alpine soil. Relative abundances of groups were derived from phylogenetic analyses of season-specific (A) fungal (Schadt et al. 2003) and (B) bacterial (Lipson and Schmidt 2004) rRNA libraries and are expressed as percentage of maximal observed seasonal abundance to emphasize temporal fluctuations for each group. Solid lines represent dynamics for changes in abundance of each group in replicate samples collected under snow, at snow melt, and in the summer. Dashed lines represent potential trajectories through fall (unsampled period). Abbreviations are: Acidos, Acidobacteria; Verrucos, Verrucomicrobia; CFB, Cytophaga Flexibacter Bacteroides.

than the alpine. For example, recent studies of coniferous forests of the Rocky Mountains are revealing significant seasonal succession of microbial communities that largely explain seasonal patterns of soil respiration (Monson et al. 2006). These soils are extremely active in the winter and over $50 \%$ of the carbon assimilated via photosynthesis per year is respired by under-snow microbial activity (Monson et al. 2006). Like tundra soils, these soils exhibit significant changes in the bacterial (Monson et al. 2006) and fungal (Fig. 1B) communities from winter to summer. Unlike tundra, however, under-snow microbial activity in these forests is fueled by rhizodeposition in addition to litter decomposition (M. Weintraub, unpublished data).

\section{Succession in the rhizosphere}

Evidence of succession of microbial communities has also recently come from detailed molecular studies of rhizosphere communities (e.g., Smalla et al. 2001, Gomes et al. 2003) and long-term studies of rootcolonizing fungi in alpine ecosystems. The rhizosphere is a very dynamic environment that receives large inputs of C substrates from plants (e.g., Norton et al. 1990). These $\mathrm{C}$ inputs fuel the rapid growth and subsequent turnover of $r$-selected microbes leading to increased $\mathrm{N}$ availability to plants (Clarholm 1985, Moore et al. 2003), but they can also sustain longer-term, more $K$-selected rhizosphere inhabitants such as mutualistic bacteria (Hirsch et al. 2003) and fungi (Smith and Read 1997). The most widespread, and best studied, examples of these fungi are the arbuscular mycorrhizal (AM) fungi. AM fungi allow plants to increase surface area for nutrient uptake, access nutrients beyond the rhizosphere, and directly obtain organic forms of N in soil (Smith and Read 1997, Hodge et al. 2001). In addition, plants can regulate their involvement with AM fungi in response to their immediate nutrient requirements (reviewed by Koide and Schreiner 1992) and recent demonstration of unexpectedly fast (5-6 day) turnover time of C associated with AM fungi (Staddon et al. 2003) indicates a high potential for successional change of these fungi on plant roots.

Studies of mycorrhizal fungi in alpine soils have provided some of the only field-based evidence that plants can use a succession of different fungal partners to access different soil nutrients over the course of a growing season. We observed succession of fungal partners in the roots of Ranunculus adoneus (Fig. 3) and found that phosphorus uptake by this plant coincided with the transitory (less than two weeks) abundance of AM arbuscules in new roots of this plant in the field (Mullen and Schmidt 1993). In contrast, all $\mathrm{N}$ uptake in $R$. adoneus occurred during and just after snowmelt when the overwintering roots were heavily infected with a novel endophytic fungus (Mullen et al. 1998). This endophyte has since been identified (Schadt et al. 2001) and shown to have high affinity uptake systems for multiple forms of organic (proteins and amino acids) and inorganic $\mathrm{N}$ (nitrate and ammonium) at temperatures that occur in the field during snowmelt $\left(0-3^{\circ} \mathrm{C} ; \mathrm{S}\right.$. K. Schmidt, unpublished data). Thus, it is likely that $R$. adoneus uses these fungal endophytes to access the snowmelt pulse of $\mathrm{N}$ in alpine soils. Some other common alpine plants (e.g., Acomastylis rossii) are also able to take up the early season pulse of $\mathrm{N}$ 


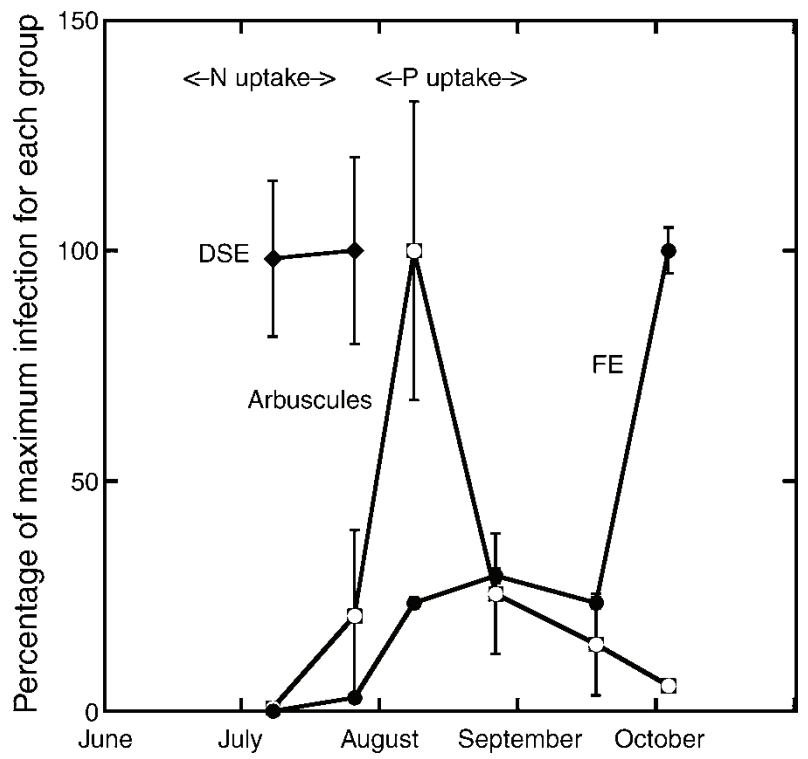

FIG. 3. Seasonal succession of fungal endophytes within the roots of field-collected snow buttercup plants (Ranunculus adoneus). The three types of fungi are dark septate endophytes (DSE), arbuscules of coarse AM fungi (arbuscules), and hyphae of a fine AM endophyte (FE). DSE were quantified in overwintering roots and correspond with the period of $\mathrm{N}$ uptake by this plant. Arbuscules and the FE appeared in new roots just prior to and during net phosphorus uptake by these plants in the field. Angle brackets at the top of the figure indicate the measured period during which most $(>90 \%)$ of the uptake occurred for each element. Data are redrawn from Mullen and Schmidt (1993) and Mullen et al. (1998). Error bars indicate \pm SE.

(Jaeger et al. 1999), but the role of fungal succession has not been studied in these species.

\section{A Temporally Explicit $N$ Cycle}

Results from temporal studies of $\mathrm{N}$ fluxes, microbial succession and turnover and timing of plant $\mathrm{N}$ uptake discussed above have provided the first year-round picture of $\mathrm{N}$ cycling in any natural ecosystem. In Fig. 4, we summarize this understanding as a temporally explicit model of the $\mathrm{N}$ cycle in alpine tundra. While this model is representative of observed dynamics in the alpine, we believe that the general ideas of microbial turnover during the plant growing season and large fluxes of $\mathrm{N}$ during seasonal transitions of microbial communities are generally applicable even though the timing and magnitude of these events will vary from system to system.

Recent models of $\mathrm{N}$ cycling have emphasized plant uptake of amino acids and microbial de-polymerization of plant litter as important and underappreciated aspects of $\mathrm{N}$ cycling in soil (Neff et al. 2003, Schimel and Bennett 2004, Chapman et al. 2006). What Fig. 4 adds to these models is an understanding of the different time scales on which microbial and plant nutrient cycling occur. With regards to de-polymerization, the discovery of wintertime peaks in fungal biomass, and depolymerizing bacteria (the CFB group) combined with high rates of de-polymerase enzyme activity under the snow, indicate that there is a temporal separation of the major period of de-polymerization from the period of plant $\mathrm{N}$ uptake. In addition, the snowmelt peak of microbial death and proteolysis provides the largest year-round pulse of DON and DIN, some of which can be taken up by specific plants (e.g., $R$. adoneus and $A$. rossii). But for many alpine plants (e.g., Deschampsia caespitosa, Kobresia myosuroides) most N uptake occurs later in the summer (Jaeger et al. 1999) and is driven by the rapid turnover of the microbial $\mathrm{N}$ cycle in the rhizosphere (Fig. 4).

Year-round seasonal succession of microbial groups and rapid turnover of microbial biomass also offer a mechanistic hypothesis for how available N (DON and DIN) is both retained and lost from ecosystems. With each turnover event or successional cycle, most $\mathrm{N}$ from the previous cycle is retaken up by microbes (Fisk et al. 1998, Lipson et al. 2001) while a smaller proportion is lost to leaching or plant uptake (Fig. 4). There should

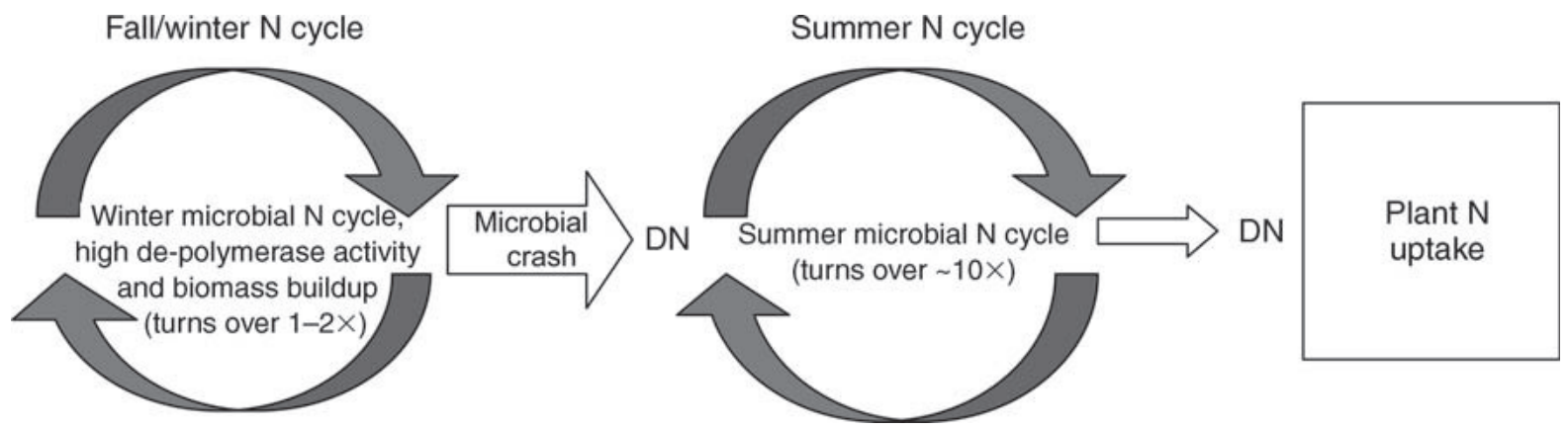

FIG. 4. A conceptual model of the succession of $\mathrm{N}$ cycles and losses from seasonally snow-covered ecosystems based on yearround studies of alpine meadows. From left to right, the fall/winter cycle is a time of microbial buildup (low turnover), high depolymerase activity, and immobilization of $\mathrm{N}$ into microbial cells. At snow melt-out, the cold-adapted (psychrophilic) microbial biomass crashes, resulting in release of dissolved $\mathrm{N}(\mathrm{DN})$. Some of this $\mathrm{N}$ is retained by growth of the snowmelt microbial community and overwintering endophytic fungi or is lost to leaching. $\mathrm{N}$ in the summer microbial community turns over approximately 10 times ( $\mathrm{N}$ turnover time of 13-18 days) and each turn of the microbial cycle releases DON and DIN. Most of this $\mathrm{N}$ is rapidly retaken up by the microbial biomass, but some may be taken up by plants and/or lost to leaching. The magnitude of $\mathrm{N}$ losses during the summer should be directly related to the rapidity of microbial turnover and relative plant demand for $\mathrm{N}$. 
therefore be a positive relationship between microbial turnover rates and $\mathrm{N}$ losses but more research is needed to test this hypothesis in other ecosystems. Better understood is the relationship between major seasonal transitions in microbial communities and $\mathrm{N}$ loss and retention by ecosystems. In the alpine, the major turnover event occurs during snowmelt when the coldadapted microbial biomass crashes (Fig. 1) resulting in a large release of DON and DIN into the soil solution (Fig. 4; Lipson et al. 1999). A large fraction of this $\mathrm{N}$ is re-immobilized by the snowmelt microbial community and a few cold-tolerant plants (Mullen et al. 1998) but much of the $\mathrm{N}$ is also lost to leaching. Similar retention and loss mechanisms during seasonal transitions occur in other ecosystems, whether they are seasonally cold (Zak et al. 1990) or seasonally dry (Vitousek and Matson 1984, Singh et al. 1989).

\section{CONCLUSION}

Our work over the last 15 years, using a myriad of independent and complementary measurements, points to a new understanding of microbial turnover and succession in soils. We have used ${ }^{15} \mathrm{~N}$-pool dilution, microbial counts and biomass methods, studies of endophytic and mycorrhizal fungi, soil enzyme assays, molecular phylogenetic surveys, and year-round internal budgets of $\mathrm{C}$ and $\mathrm{N}$ fluxes to show that soil microbial activity and phylogenetic composition changes dramatically on very short time scales in alpine soils. This new understanding of soil microbial ecology has now reached a point where it needs to be integrated with larger-scale ecological and biogeochemical theory. In this paper, we argue that the turnover and succession of microbial communities is an important missing piece in our understanding of nutrient cycling in terrestrial ecosystems and in fact provides a mechanistic explanation for several poorly understood phenomena in terrestrial ecosystems. For example, our work indicates that microbial turnover and succession provides an important source and sink of dissolved organic N (DON) and inorganic $\mathrm{N}$ (DIN) in alpine soils. Furthermore we contend that turnover of microbial cells is the most important source of DON and DIN for plant growth in this system and that the largest year-round losses of $\mathrm{N}$ occur when the microbial biomass undergoes a major turnover event during snowmelt. Finally, our understanding of microbial turnover and succession has important implications for studies of microbial community composition in nature. The composition of the microbial community can change on short time scales in soil, making it impossible to assess microbial diversity for a site or soil type without a year-round sampling regime that captures the various microbial communities occurring at a site over the course of a year.

\section{ACKNOWLEDGMENTS}

We thank D. Lipson, C. Schadt, R. Mullen, M. Fisk, P. Brooks, A. West, W. Bowman, R. Ley, M. Williams, T. Seastedt, A. Townsend, and R. Monson for helpful discussions and the use of data. This work was supported by grants from the National Science Foundation of the USA (MCB0084223, MCB0455606, DEB0455606, and IBN-0212267). The Niwot Ridge LTER program and the Mountain Research Station at the University of Colorado provided logistical support for the field portions of this work.

\section{Literature Cited}

Bardgett, R. D., W. D. Bowman, R. Kaufmann, and S. K. Schmidt. 2005. Linking aboveground and belowground ecology: A temporal approach. Trends in Ecology and Evolution 20:534-541.

Boetius, A., K. Ravenschlag, C. Schubert, D. Rickert, F. Widdel, A. Gleseke, R. Amann, B. B. Jørgensen, U. White, and O. Pfannkuche. 2000. A marine microbial consortium apparently mediating anaerobic oxidation of methane. Nature 407:623-626.

Brooks, P. D., M. W. Williams, and S. K. Schmidt. 1998. Inorganic $\mathrm{N}$ and microbial biomass dynamics before and during spring snowmelt. Biogeochemistry 43:1-15.

Butler, J. L., P. J. Bottomley, S. M. Griffith, and D. D. Myrold. 2004. Distribution and turnover of recently fixed photosynthate in ryegrass rhizospheres. Soil Biology and Biochemistry 36:371-382.

Chapman, S. K., J. A. Langley, S. C. Hart, and G. W. Koch. 2006. Plants actively control nitrogen cycling: uncorking the microbial bottleneck. New Phytologist 169:27-34.

Clarholm, M. 1985. Interactions of bacteria, protozoa and plants leading to mineralization of soil nitrogen. Soil Biology and Biochemistry 17:181-187.

Davidson, E. A., S. C. Hart, and M. K. Firestone. 1992. Internal cycling of nitrate in soils of a mature coniferous forest. Ecology 73:1148-1156.

Fenchel, T. 2002. Microbial behavior in a heterogeneous world. Science 296:1068-1071.

Fierer, N., M. A. Bradford, and R. B. Jackson. 2007. Toward an ecological classification of soil bacteria. Ecology 88:1354 1364.

Fisk, M. C., S. K. Schmidt, and T. Seastedt. 1998. Topographic patterns of above- and belowground production and nitrogen cycling in alpine tundra. Ecology 79:2253-2266.

Garcia-Pichel, F., and O. Pringault. 2001. Cyanobacteria track water in desert soils. Nature 413:380-381.

Gomes, N. C. M., O. Fagbola, R. Costa, N. G. Rumjanek, A. Buchner, L. Mendona-Hagler, and K. Smalla. 2003. Dynamics of fungal communities in bulk and maize rhizosphere soil in the tropics. Applied and Environmental Microbiology 69: 3758-3766.

Grenon, F., R. L. Bradley, M. D. Jones, B. Shipley, and H. Peat. 2005. Soil factors controlling mineral $\mathrm{N}$ uptake by Picea engelmannii seedlings: the importance of gross $\mathrm{NH}_{4}^{+}$ production rates. New Phytologist 165:791-800.

Hamilton, E. W., and D. A. Frank. 2001. Can plants stimulate soil microbes and their own nutrient supply? Evidence from a grazing tolerant grass. Ecology 82:2397-2402.

Hirsch, A. M., W. D. Bauer, D. M. Bird, J. Cullimore, B. Tyler, and J. I. Yoder. 2003. Molecular signals and receptors: controlling rhizosphere interactions between plants and other organisms. Ecology 84:858-868.

Hobbie, S. E., and F. S. Chapin. 1996. Winter regulation of tundra litter carbon and nitrogen dynamics. Biogeochemistry 35:327-338.

Hodge, A., C. D. Campbell, and A. H. Fitter. 2001. An arbuscular mycorrhizal fungus accelerates decomposition and acquires nitrogen directly from organic material. Nature 413:297-299.

Holmes, W. E., and D. R. Zak. 1999. Soil microbial control of nitrogen loss following clear-cut harvest in northern hardwood ecosystems. Ecological Applications 9:202-215.

Jaeger, C. H., R. K. Monson, M. C. Fisk, and S. K. Schmidt. 1999. Seasonal partitioning of nitrogen by plants and soil 
microorganisms in an alpine ecosystem. Ecology 80:18831891.

Janssen, P. H. 2006. Identifying the dominant soil bacterial taxa in libraries of 16S rRNA and 16S rRNA genes. Applied and Environmental Microbiology 72:1719-1728.

Koch, A. L. 1976. How bacteria face depression, recession, and derepression. Perspectives in Biology and Medicine 20:44-63.

Koide, R. T., and R. P. Schreiner. 1992. Regulation of the vesicular-arbuscular mycorrhizal symbiosis. Annual Review of Plant Physiology 43:557-581.

Könneke, M., A. E. Bernhard, J. R. de la Torre, C. B. Walker, J. B. Waterbury, and D. A. Stahl. 2005. Isolation of an autotrophic ammonia-oxidizing marine archaeon. Nature 437:543-546.

Lipson, D. A., T. K. Raab, S. K. Schmidt, and R. K. Monson. 2001. An empirical model of amino acid transformations in alpine soil. Soil Biology and Biochemistry 33:189-198.

Lipson, D. A., C. W. Schadt, and S. K. Schmidt. 2002. Changes in microbial community structure and function in an alpine dry meadow following spring snow melt. Microbial Ecology 43:307-314.

Lipson, D. A., and S. K. Schmidt. 2004. Seasonal changes in an alpine soil bacterial community in the Colorado Rocky Mountains. Applied and Environmental Microbiology 70: 2867-2879.

Lipson, D. A., S. K. Schmidt, and R. K. Monson. 1999. Links between microbial population dynamics and nitrogen availability in an alpine ecosystem. Ecology 80:1623-1631.

Monson, R. K., D. A. Lipson, S. P. Burns, A. A. Turnipseed, A. C. Delany, M. W. Williams, and S. K. Schmidt. 2006. Winter forest soil respiration controlled by climate and microbial community composition. Nature 439:711-714.

Moore, J. C., K. McCann, H. Setälä, and P. C. de Ruiterd. 2003. Top-down is bottom-up: does predation in the rhizosphere regulate aboveground dynamics? Ecology 84: 846-857.

Mullen, R. B., and S. K. Schmidt. 1993. Mycorrhizal infection, phosphorus uptake, and phenology in Ranunculus adoneus: Implications for the functioning of mycorrhizae in alpine systems. Oecologia 94:229-234.

Mullen, R. B., S. K. Schmidt, and C. H. Jaeger. 1998. Nitrogen uptake during snowmelt by the snow buttercup, Ranunculus adoneus. Arctic and Alpine Research 30:121-125.

Myers, R. T., D. R. Zak, D. C. White, and A. Peacock. 2001. Landscape-level patterns of microbial community composition and substrate use in upland forest ecosystems. Soil Science Society of America Journal 65:359-367.

Neff, J. C., F. S. Chapin, and P. M. Vitousek. 2003. Breaks in the cycle: dissolved organic nitrogen in terrestrial ecosystems. Frontiers Ecology Environment 1:205-211.

Neidhardt, F. C., J. L. Ingraham, and M. Schaechter. 1990. Physiology of the bacterial cell; a molecular approach. Sinauer Associates, Sunderland, Massachusetts, USA.

Nemergut, D. R., S. P. Anderson, C. C. Cleveland, A. P. Martin, A. E. Miller, A. Seimon, and S. K. Schmidt. 2007. Microbial community succession in an unvegetated, recentlydeglaciated soil. Microbial Ecology 53:110-122.

Norton, J. M., J. L. Smith, and M. K. Firestone. 1990. Carbon flow in the rhizosphere of ponderosa pine seedlings. Soil Biology and Biochemistry 22:449-455.

Ostle, N., A. S. Whitely, M. J. Bailey, D. Sleep, P. Ineson, and M. Manefield. 2003. Active microbial RNA turnover in a grassland soil estimated using a ${ }^{13} \mathrm{CO}_{2}$ spike. Soil Biology and Biochemistry 35:877-885.

Perakis, S. S., and L. O. Hedin. 2001. Fluxes and fates of nitrogen in soil of an unpolluted old-growth temperate forest, Southern Chile. Ecology 82:2245-2260.

Purcell, E. M. 1977. Life at low Reynolds number. American Journal of Physics 45:3-11.

Rangle-Castro, J. I., J. I. Prosser, N. Ostle, C. M. Scrimgeour, K. Killham, and A. A. Meharg. 2005. Flux and turnover of fixed carbon in soil microbial biomass of limed and unlimed plots of an upland grassland ecosystem. Environmental Microbiology 7:544-552.

Rappé, M. S., and S. J. Giovannoni. 2003. The uncultured microbial majority. Annual Review of Microbiology 57:369394.

Schadt, C. W., A. P. Martin, D. A. Lipson, and S. K. Schmidt. 2003. Seasonal dynamics of previously unknown fungal lineages in tundra soils. Science 301:1359-1361.

Schadt, C. W., R. B. Mullen, and S. K. Schmidt. 2001. Isolation and phylogenetic identification of a dark-septate fungus associated with the alpine plant Ranunculus adoneus. New Phytologist 150:747-755.

Schimel, J. P., and J. Bennett. 2004. Nitrogen mineralization: challenges of a changing paradigm. Ecology 85:591-602.

Schloss, P. D., and J. Handelsman. 2004. Status of the microbial census. Microbiology and Molecular Biology Reviews. 68:686-691.

Schmidt, S. K., and D. A. Lipson. 2004. Microbial growth under the snow: implications for nutrient and alleochemical availability in temperate soils. Plant and Soil 259:1-7.

Schmidt, S. K., D. A. Lipson, and T. K. Raab. 2000. Effects of willows (Salix brachycarpa) on populations of salicylatemineralizing microorganisms in alpine soils. Journal of Chemical Ecology 26:2049-2057.

Singh, J. S., A. S. Raghubanshi, R. S. Singh, and S. C. Srivastava. 1989. Microbial biomass acts as a source of plant nutrients in dry tropical forest and savanna. Nature 338:499500 .

Sinsabaugh, R. L. 2005. Fungal enzymes at the community scale. Pages 249-262 in J. Dighton, P. Oudermans, and J. White, editors. The fungal community. Third edition. CRC Press, Boca Raton, Florida, USA.

Sinsabaugh, R. L., M. M. Carreiro, and S. Alvarez. 2002. Enzyme and microbial dynamics of litter decomposition. Pages 249-265 in R. G. Burns and R. P. Dick, editors. Enzymes in the environment: activity, ecology and applications. Marcel Dekker, New York, New York, USA.

Smalla, K., G. Wieland, A. Buchner, A. Zock, J. Parzy, S. Kaiser, N. Roskot, H. Heuer, and G. Berg. 2001. Bulk and rhizosphere soil bacterial communities studied by denaturing gradient gel electrophoresis: plant-dependent enrichment and seasonal shifts revealed. Applied and Environmental Microbiology 67:4742-4751.

Smith, S. E., and D. J. Read. 1997. Mycorrhizal symbiosis. Second edition. Academic Press, San Diego, California, USA.

Staddon, P. L., C. B. Ramsey, N. Ostle, P. Ineson, and A. H. Fitter. 2003. Rapid turnover of mycorrhizal fungi determined by AMS microanalysis of ${ }^{14} \mathrm{C}$. Science $300: 1138-1140$.

Stark, J. M., and S. C. Hart. 1997. High rates of nitrification and nitrate turnover in undisturbed coniferous forests. Nature 385:61-64.

Stottlemeyer, R., and D. Toczydlowski. 1999. Nitrogen mineralization in a mature boreal forest, Isle Royale, Michigan. Journal of Environmental Quality 28:709-720.

Taylor, B. R., and H. G. Jones. 1990. Litter decomposition under snow cover in a balsam fir forest. Canadian Journal of Botany 68:112-120.

Thormann, M. N., R. S. Currah, and S. E. Bayley. 2003. Succession of microfungal assemblages in decomposing peatland plants. Plant and Soil 250:323-333.

Torsvik, V., L. Øvreås, and T. F. Thingstad. 2002. Prokaryotic diversity: magnitude, dynamics, and controlling factors. Science 296:1064-1066.

Vitousek, P. M., and P. A. Matson. 1984. Mechanisms of nitrogen retention in forest ecosystems: a field experiment. Science 225:51-52.

Zak, D. R., P. M. Groffman, K. S. Pregitzer, S. Christensen, and J. M. Tiedje. 1990. The vernal dam: plant-microbe competition for nitrogen in northern hardwood forests. Ecology 71:651-656. 